\title{
Adaptation and mitigation strategies to climate change by smallholder dairy farmers: A case of Nandi county in Kenya
}

\author{
Josephine Wangechi Kirui ${ }^{* 1}$, Nzioka John Muthama², Charles Karuku Gachuiri ${ }^{3}$, \\ Joshua Ndiwa Ngaina ${ }^{4}$ \\ ${ }^{1}$ University of Nairobi, Kenya \\ ${ }^{2}$ Wangari Maathai Institute for Peace and Environmental Studies, University of Nairobi, Kenya \\ ${ }^{3}$ Faculty of Veterinary Medicine, University of Nairobi, Kenya \\ ${ }^{4}$ School of Environment, Water and Natural Resources Management, South Eastern Kenya University
}

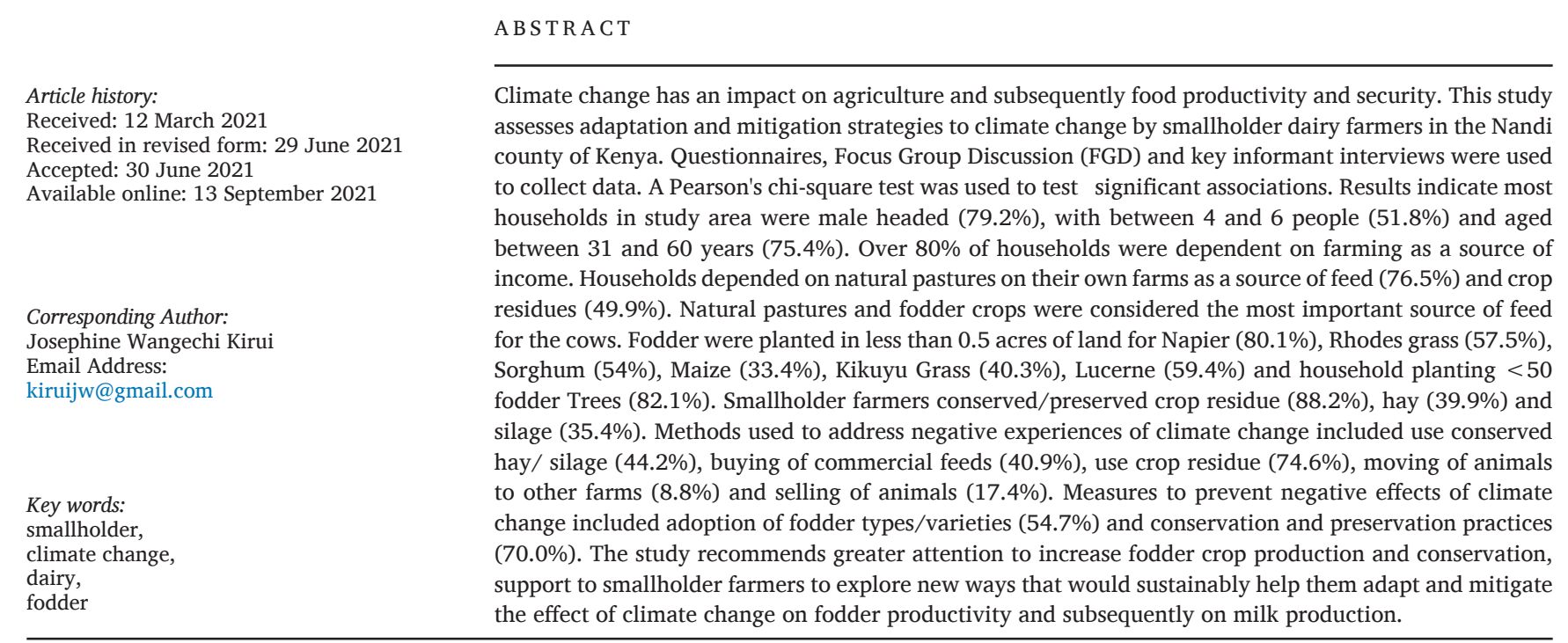

\section{Introduction}

Climate change and agriculture are inextricably linked. Agriculture still depends fundamentally on the weather. Climate change has already caused a negative impact on agriculture in many parts of the world because of increasingly severe weather patterns. Climate change alters the rainfall patterns and temperatures and ultimately impacts on the local seasonal and annual water-distribution, with a resulting negative effect on both agriculture and subsequent food productivity and security (Herrero, et al., 2009). Based on IPCC assessment report (IPCC, 2013), there is high likelihood of an increase in global temperatures (between $0.3^{\circ} \mathrm{C}$ and $4.8^{\circ} \mathrm{C}$ ) by 2100 with potential impacts primarily due to an increase in temperature and atmospheric carbon dioxide $\left(\mathrm{CO}_{2}\right)$ concentration, precipitation variation, and a combination of these factors expected to include changes in production and quality of feed crop and forage (Chapman et al., 2012; Polley et al., 2013), water availability (Nardone et al., 2010; Henry et al., 2012), animal growth and milk production (Nardone et al., 2010; Henry et al., 2012), diseases (Nardone et al., 2010), reproduction (Nardone et al., 2010), and biodiversity.

Climate change is expected to continue to cause drought, floods, worsen desertification and disrupt growing seasons. Climate change and food security are related because climate change can directly affect a country's ability to feed its people. However, IPCC report (2007) showed that climate change will not equally affect all countries and will likely have the biggest impact in equatorial regions such as sub-Saharan Africa. This means that countries already struggling with food security are likely to find themselves struggling harder in future.

Agriculture is the backbone of economic activities in the 
Kenya, while animal rearing is widely practiced with most households opting to keep cattle for both the production of beef and dairy products. Milk is expected to contribute greatly in meeting the new demand for food security through provision of animal protein. The Kenya Dairy subsector dominated by about one million smallholders is important and contributes to improved nutrition and employment in rural areas and accounts for $80 \%$ of the milk produced. The per capita milk consumption in Kenya is expected to be above the 78kgs/person/year projection by FAO for developing countries by the year 2050, and one of the largest in the developing countries (Republic of Kenya, 2008; TEGEMEO, 2011).

Practices that sustainably increase agricultural productivity and resilience and enhance national food security while in mitigation reducing or removing GHG emissions are referred to as Climate Smart Agriculture (CSA) (Chaudhury et al., 2012). According to FAO (2010) CSA are vulnerability reduction approaches that aim at helping the mainly subsistence and rural small-scale farmers to adapt to changes in climate through diversification or intensification of their livelihood strategies. It involves adopting new agro-ecological and socio-economic agricultural production systems that achieve higher productivity and lower output variability within the context of climate-change risks. CSA practices are concerned with management of soils and nutrients, harvesting of water, conservation and pest and disease control practices and/ or resilient ecosystems (CGIAR, 2015). Other CSA practices include increasing soil organic matter, practicing mixed-species forestry or agro-forestry to improve the soil quality and reduction of impacts of droughts and/or floods. It is concerned with efficient water management, a critical and a far-reaching adaptation and livelihood goal to a resource that is threatened by climate change (Hobbs et al., 2008). Water resource management include adopting better irrigation practices, adoption of better water harvesting technology, and inclusion of terrace or contour farming systems to contribute to improved water-use efficiency and conservation. Incorporating shifts in hydrologic regimes and water availability in response to changes in climate and incorporating these shifts in design and management of water resources and systems is a concern under CSA that enhances adaptation.

CSA aims at sustainable intensification of agriculture production systems to increase and enhance productivity thus contributing to achievement of national food security and to the attainment of development goals (FAO, 2015). As a strategy, it aims at safeguarding the SDGs and reducing the vulnerability of rural communities' socio-economically, especially in developing countries. Furthermore, it aims at increasing the resilience of agriculture production systems and rural livelihoods and at reduction of agriculture's GHG emissions through increased production efficiency and in mitigation, increase carbon sequestration. Investing in CSA aims at smartly meeting growing global demand for food within changing climate (Hobbs et al., 2008). However, scarcity of climate-smart fodder varieties, inadequate rainfall, recurrent and prolonged drought are major factors contributing to insufficient quality and quantity of feed. Fodder production systems in Kenya are mainly rain-fed and farmers have limited ability to prepare for dry periods and appropriate feeding regimes. Therefore, for most farmers, the production and sales activities are suboptimal. Therefore, this study sought to establish adaptation and mitigation measures put in place by smallholder farmers that can cushion them against the effect of climate change. The methods considered in the study used to address negative experiences of climate change include use conserved hay/ silage, buy commercial feeds, use crop residue, move animals to other farms or sell of animals. In terms of mitigation measures to negative effect of climate change, the strategies considered in the study include adoption of new fodder types/ varieties, adoption of new planning methods, intercropping different fodder, and conservation and preservation practices while climate Smart Agricultural technologies include compost making, use of biogas, water conservation, disease control, planting fodder trees, reducing number of animals and breeding using Artificial intelligence (AI).

\section{Data and Method}

The study was in Nandi County which falls within the agro-ecological zones of Upper Highland (UH) to Upper Midland (UM) and is one of the major dairy zones in Kenya predominately smallholder dairy farming that mainly rely on rain fed fodder production. Mean rainfall is between 1,200-2,000 millimeters per year and bimodal between dry spells between December and March. Rainfall distribution varies according to topography and is influenced by south-westerly winds from Lake Victoria. Major staple crops in the area include maize, millet, sorghum, and potatoes while pyrethrum, tea and coffee are main cash crops. The farmers practice intensive and semi intensive dairy farming. Dairy farmers in Nandi grow forage crops such as Nandi setaria (Setariasphacelata), Rhodes grass (Chloris gayana), and Napier grass (Pennisetum purpureum). Smallholder farmers market their milk using different milk-marketing channels: either through an informal milk market where milk is sold to middlemen or hotels or through formal market where milk is marketed through farmers' organizations' marketing channel.

The study used concurrent triangulation research design which allows for mixed-methods research methodologies. This design enables concurrent collection of both qualitative and quantitative data in one phase which can then be analysed separately. The data collected at household $(\mathrm{HH})$ level used in the study included sources of livestock feed, fodder/pasture planted for dairy production, fodder availability for future use, resilience and adaptations approaches used to address climate change and measures to prevent negative impact of climate change in addition to key household characteristics such as age, gender, education, income level, and wealth status. Questionnaires were administered to dairy farmers in five (5) sub counties of Nandi County which included Aldai (Kaptumo, Kobujoi, Koyo-Ndurio), Chesumei (Kosirai, Ngechek), Emgwen (Kilibwoni), Mosop (Kabisaga, Kabiyet) and Nandi Hills (Chepkunyuk, Lessos). The mathematical formula of determining a sample size from a given population by Krejcie \& Morgan (1970) was used as follows.

$$
s=X^{2} N P(1-P) \div d^{2}(N-1)+X^{2} P(1-P)
$$

Where $\mathrm{s}$ is the required sample size, $\mathrm{X}^{2}$ is the table value of chi-square for 1 degree of freedom at the desired confidence level (3.841), $\mathrm{N}$ is the population size (300000), $\mathrm{P}$ is the population proportion (assumed to be .50 since this would provide 
the maximum sample size) and $d$ is the degree of accuracy expressed as a proportion (.05). Therefore, the required sample size was given as $3.841 \times 300000 \times 0.5(1-0.5) \div 0.05 \times 0.05$ $(300000-1)+3.841 \times 0.5(1-0.5)$ which resulted to a sample size of 384. In addition, focus group discussion (FGD) and key informant interviews were used. Purposive Sampling was used to target experts who have in-depth knowledge on adaptation and mitigation strategies to climate change used in the Nandi County from the Ministry of Agriculture Livestock and Fisheries (MALF), the dairy cooperatives, Kenya Dairy Board (KDB) and the Kenya Agriculture and Livestock Organisation (KALRO). The study also used a systematic random sampling technique to identify household (HH) involved in smallholder dairy production and grow fodder. A Chi-Square $\left(\chi^{2}\right)$ test was computed to assess the relationship between the different variables. The calculation of the Chi-Square statistic is quite straight-forward and intuitive:

$$
\chi^{2}=\sum \frac{\left(f_{o}-f_{e}\right)^{2}}{f_{e}}
$$

where $f_{o}=$ the observed frequency and $f_{e}=$ the expected frequency if NO relationship existed between the variables. Based on chi square test, the hypothesis tested included significant association between (i) respondents and the main source of feed, (ii) acreage of fodder planted and maize, sorghum and lucerne and (iii) farmers that conserved or preserved fodder for future use.

\section{Results and Discussion}

Information on existing and potential adaptation and mitigation strategies to climate change was collected based on questionnaires, focus group discussion and key informant interviews.

\subsection{Response rate and household characteristics}

Of the 384 questionnaires distributed, only 382 questionnaires were found to be fit for analysis as two questionnaires were partially filled. This gave a response rate of $99.5 \%$. This was possible because the researcher and the enumerators administered the questionnaires and hence eliminated the risk of non-return as it was possible to recover the questionnaires once they were completed. The response rate based on gender (Table 1) indicates that male respondents were $59.8 \%$ compared to female who were $40.2 \%$ in all wards considered except Kosirai ward in Chesumei subcounty.

Fig. 1 (a) show that $79.2 \%$ of household in Nandi County were male headed. Out of this, $64.1 \%$ of the respondents were HH heads (Fig. 1 (b). In addition, majority of household in Aldai, Chesumei, Emgwen, Mosop and Nandi Hills sub counties of Nandi County were male headed. This finding agrees with other similar studies that found that males are more involved in smallholder dairy farming than their female counter parts with only a small percentage of young people aged being interested in dairy farming. In addition, Gallina (2016) noted that dairy production being a family operation required that all family members led by the HH head contribute to the day to day dairy production.

The Fig. 1 (c) shows that majority of HH in Aldai (Kaptumo,
Kobujoi, Koyo Ndurio), Chesumei (Kosirai, Ngechek), Emgwen (Kilbwoni) and Nandi Hills composed of 4 to 6 people while $\mathrm{HH}$ Mosop (Kabisaga, Kabiyet) had more than 6 people and thus majority of $\mathrm{HH}(51.8 \%)$ in the county had between 4 and 6 people. The Fig. 1 (d) shows that $75.4 \%$ of HH heads in Nandi County were between the age of 31 and 60. Majority of $\mathrm{HH}$ heads in Aldai and Emgwen sub counties were between the ages of 46 and 60 years whereas in Chesumei, Nandi Hills and Mosop sub counties, majority of HH head were between the age of 31 and 45 years. The study assumed that the age differences contributed to the experience in dairy farming such that older population are considered less productive but more settled and experienced compared to younger population. However, age may also be a limiting factor when it comes to innovation as younger people are considered innovative. According to government of Kenya, the average age of a farmer is 60 years. Studies show that there is decline of youth interest in agriculture. Although agricultural sector provide great opportunity, youth involvement in agriculture is declining in Africa; Kenya included (Mibey, 2015) as youth perceived agriculture as a low status profession practiced by old, illiterate and poor rural people since majority of African farmers were aged 55-70 years (Njeru et al., 2015). Moreover, young people have limited access to credit facilities that hinder their ability to invest in smallholder dairy farming. However, this group of young people can still be involved in dairy farming through value addition and milk value chain and ultimately expected to engage in milk production once they realize the potential provided by the sector.

As shown in Fig. 1 (e), most of the HH head had attained primary education and above in all sub counties of Nandi County. Majority of HH heads in Aldai, Chesumei and Nandi Hills sub counties had attained secondary education while majority of $\mathrm{HH}$ heads in Emgwen had attained primary education. In overall, $34.6 \%$ of the respondents in Nandi County had attained secondary education whereas more than $33 \%$ had post-secondary education. The studies noted that farmers with formal education were more likely to adopt new technologies and are also more innovative. Limited education levels are likely to negatively affect the adoption of new and improved milk production practices by farmers which may led to low milk production. In addition, a farmer with education is able to increase their environmental awareness and ability to obtain and process information as education boosts the farmers' ability to identify beneficial coping alternatives.

The Fig. 2 (a) shows that majority ( $>80.1 \%$ ) of respondents in Aldai, Chesumei, Emgwen, Mosop and Nandi Hills are farmers. Moreover, the Fig. 2 (a) indicated that majority of these respondents' main source of income was farming in Aldai (95.9\%), Chesumei (80.6\%), Emgwen (81.4\%), Mosop (90.9\%) and Nandi Hills (77\%). In Overall, over $80 \%$ of respondents are mainly dependent on farming as a source of income in Nandi County. The Fig. 2 (b) show that in majority of HH in Nandi County owned Radio, Television (94.9\%) and cell phones (96.5\%). Majority of HH in Aldai, Chesumei and Nandi Hills had solar panel/electricity whereas; majority in Mosop had vehicles $(57.6 \%)$ with very few $\mathrm{HH}$ owning vehicles $(20.8 \%)$ and tractor $(10.5 \%)$.

Table 2 shows computed $\chi^{2}$ values to be greater that the critical chi square values between the type of $\mathrm{HH}$ with age group $\left(\chi^{2}=47.61\right)$, level of education $\left(\chi^{2}=25.18\right)$, Occupation 
$\left(\chi^{2}=11.34\right)$, source of Income $\left(\chi^{2}=39.47\right)$, HH ownership (Cell phone) $\left(\chi^{2}=13.63\right)$, HH ownership (Solar Panel) $\left(\chi^{2}=\right.$ 21.72), HH ownership (Vehicle) $\left(\chi^{2}=14.85\right)$, and HH ownership. (Tractor) $\left(\chi^{2}=14.17\right)$ and hence an indication of a statistically significant association.

\subsection{Sources of Livestock feed}

Table 3 shows that in Aldai sub county, 86.9\% of respondent's animal feeds were natural pastures from their own farms while $62.6 \%$ relied on crop residues as feed resource. Further, $39.4 \%$ indicated that they planted fodder whereas $19.2 \%$ and $16.2 \%$ noted that they sourced their feeds from communal land (natural pasture) or purchased fodder respectively. In Chesumei Sub County, $71.6 \%$ sourced their feeds from natural pastures on their own farms, $44.8 \%$ planted fodder or relied on crop residue as feed resource whereas only $7.5 \%$ sourced their feeds from either communal land or purchased fodder. In Emgwen Sub County, $80.7 \%$ depended on natural pastures from their own farms with $43.9 \%$ planting their fodder while $36.8 \%$ used crop residue.

In Mosop Sub County, $89.7 \%$ utilized crop residue as their source of feed while $51.7 \%$ used natural pasture from their own farms while $17.2 \%$ planted fodder. In Nandi hills, $74.2 \%$ sourced their animal feeds from natural pastures on their own farms with crop residue accounting for $35.5 \%$ of feeds while planted fodder accounted for $29.0 \%$. In overall, the study found that $76.5 \%$ of the household in Nandi County mainly depended on natural pastures on their own farms as a source of feed followed by $49.9 \%$ who relied on crop residue and $36.5 \%$ had planted fodder. Table 3 shows calculated chi square values identifying the main source of livestock feed per subcounty to be natural pasture from communal land, own farm and crop residue were greater than the critical chi square values. Chi square test indicated that there is significant association between respondents and the main source of feed. However, respondents did not show significant association with planted and purchased fodder.

The FDG identified Kikuyu grass, Nandi Sateria and other natural grasses to form the bulk of natural pastures, maize stovers was the main crop residue while Napier grass and Rhodes grass formed the bulk of planted fodder. This result concurs with Njaruai et al. (2011), who stated in a study that most of the households in Kenya devote $23-40 \%$ of household land to feed production of Napier and Rhodes grass and the rest under natural pastures or fallow. The FGD identified crops grown in Nandi County to include tea, maize, coffee, Sugar cane, vegetables, and fruits. Apart from dairy farming, other key activities were

\begin{tabular}{|c|c|c|c|c|c|c|}
\hline \multirow{2}{*}{ Sub County } & \multirow{2}{*}{ Ward } & \multicolumn{2}{|c|}{ Male } & \multicolumn{2}{|c|}{ Female } & \multirow{2}{*}{$\begin{array}{c}\text { Total } \\
\text { Frequency (n) }\end{array}$} \\
\hline & & Frequency (n) & Percentage (\%) & Frequency (n) & Percentage (\%) & \\
\hline \multirow{2}{*}{ Aldai } & Kaptumo & 24 & 55.8 & 19 & 44.2 & 43 \\
\hline & Kobujoi & 5 & 31.3 & 11 & 68.8 & 16 \\
\hline \multirow{2}{*}{ Chesumei } & Koyo Ndurio & 37 & 59.7 & 25 & 40.3 & 62 \\
\hline & Chesumei & 4 & 17.4 & 19 & 82.6 & 23 \\
\hline \multirow{2}{*}{ Emgwen } & Ngechek & 30 & 68.2 & 14 & 31.8 & 44 \\
\hline & Emgwen & 42 & 72.4 & 16 & 27.6 & 58 \\
\hline \multirow{2}{*}{ Mosop } & Kabisaga & 13 & 68.4 & 6 & 31.6 & 19 \\
\hline & Kabiyet & 8 & 57.1 & 6 & 42.9 & 14 \\
\hline \multirow{3}{*}{ Nandi Hills } & Chepkunyuk & 27 & 79.4 & 7 & 20.6 & 34 \\
\hline & Lessos & 36 & 55.4 & 29 & 44.6 & 65 \\
\hline & Total & & 59.8 & & 40.2 & \\
\hline
\end{tabular}

(Source: Research Data, 2021)
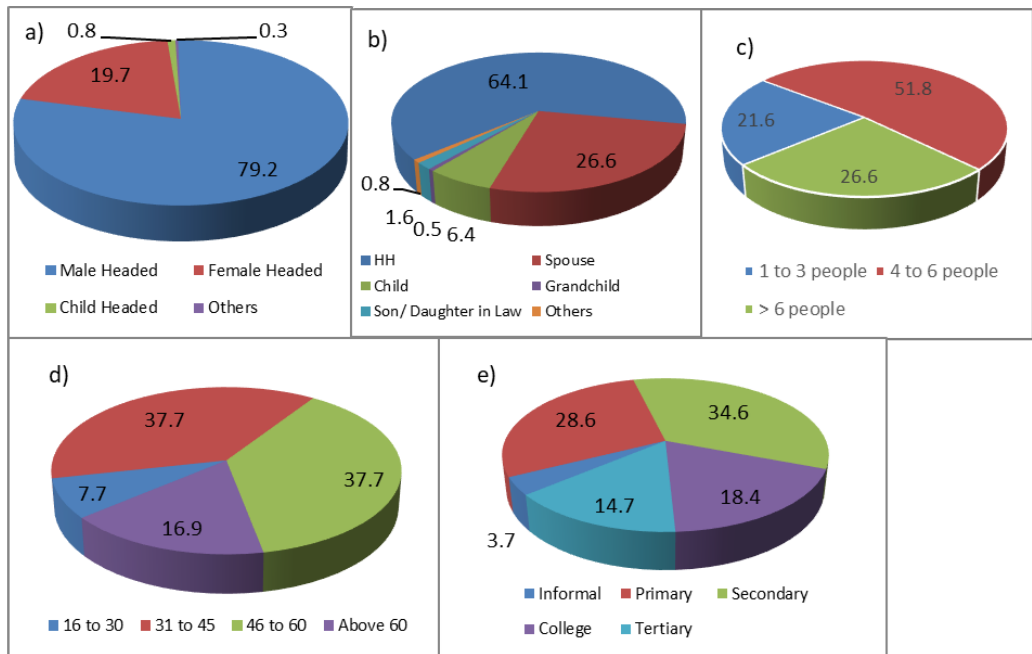

Fig. 1: Analysis of the a) type of $\mathrm{HH} \mathrm{b}$ ) relationship of respondent to $\mathrm{HH}$ head c) number of people in the $\mathrm{HH}$ d) age distribution of $\mathrm{HH}$ head and e) level of education of HH Head (Source: Research Data, 2021) 


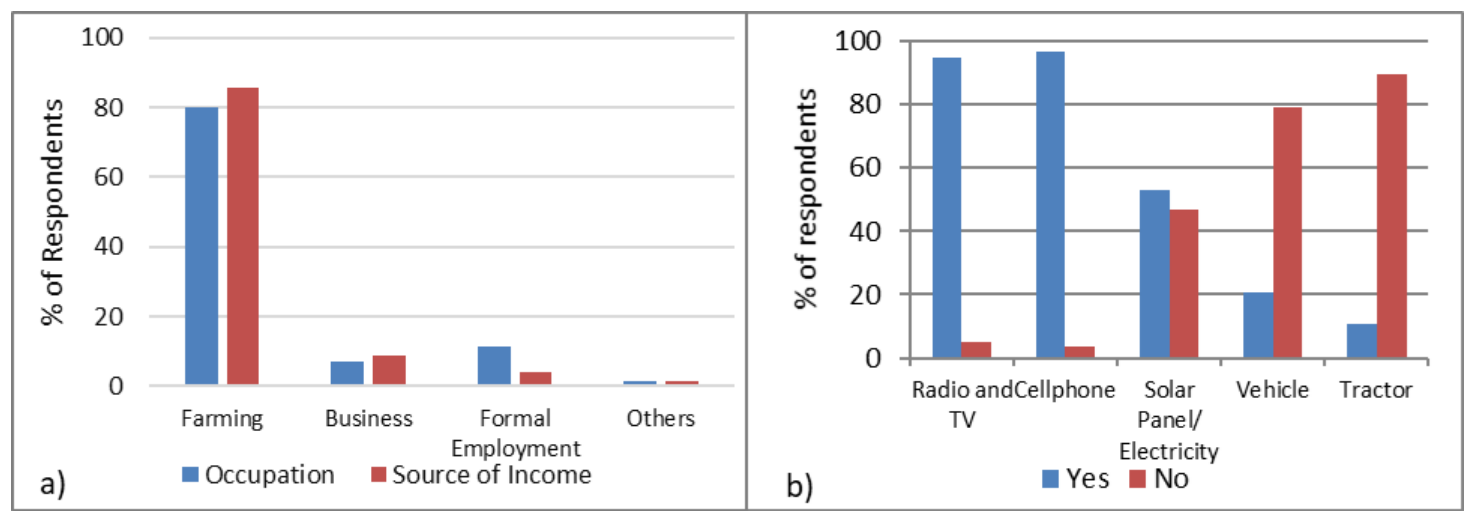

Fig. 2: Analysis showing a) main occupation/source of income and b) wealth status of Household in Nandi County. (Source: Research Data, 2021)

mainly tea picking and weeding with women noted to form the bigger labour force. In dairy farming, men were noted to ; be mainly involved in breeding, disease control and other seasonal activities like fodder planting, harvesting and storing whereas women were involved in daily activities such as feeding, watering and milking which agrees with studies (Njaruri et al., 2012). The FGD identified the natural pastures and fodder crops grown in Nandi County to comprise of Kikuyu grass, Nandi Sateria, and other Natural grasses are the most important in terms of providing feed for the cows. Moreover, it was noted that most farmers relied on natural grasses while planted grass such as Napier grass was the second most important fodder as many farmers had planted whereas the Rhodes grass was ranked third in terms of importance. The FGD also noted that dairy farmers utilized maize crops for their animals with a few of them planting maize for making silage while others use green maize stock after selling maize cob. Farmers also used dry stovers after harvesting maize.

Table 2: Chi-Square test (Association with type of $\mathrm{HH}$ at $\alpha=0.05$ )

\begin{tabular}{llll}
\hline Variable & Chi Square & P Value & $\begin{array}{l}\text { Critical } \\
\text { Value }\end{array}$ \\
\hline Age group & 47.61 & 0.000 & 21.03 \\
Level of education & 25.18 & 0.048 & 25.00 \\
Occupation & 11.34 & 0.250 & 16.92 \\
Source of Income & 39.47 & 0.000 & 21.03 \\
HH ownership (Radio \& TV) & 12.06 & 0.060 & 12.59 \\
HH ownership (Cell phone) & 13.63 & 0.030 & 12.59 \\
HH ownership (Solar Panel) & 21.72 & 0.001 & 12.59 \\
HH ownership (Vehicle) & 14.85 & 0.020 & 12.59 \\
HH ownership (Tractor) & 14.17 & 0.030 & 12.59 \\
\hline Source Research Data, 2021 & & & \\
& & &
\end{tabular}

\subsection{Fodder/Pasture planted for dairy production}

Table 4 and Table 5, up to $75.5 \%, 56.0 \%$ and $57.1 \%$ of respondents in Aldai sub county indicated that they planted Napier, Rhodes grass, and Lucerne and fodder trees respectively in less than 0.5 acres of land respectively while maize (54.5\%) and sorghum (65.5\%) were planted on 0.5 to 2 acres of land with regard to fodder tree $85.7 \%$ had planted between 1 and 50 trees. In Chesumei Sub County, all households planted Lucerne with majority of the respondents planting Napier (93.3\%), Rhodes grass (64.3\%), sorghum (88.9\%) and Kikuyu grass $(72.7 \%)$ in in less than 0.5 acres of land with $80 \%$ of respondents planting (1 to 50 ) fodder trees. Similarly, in Emgwen Sub County, all households planted lucerne with majority of the respondents planting Napier (82.9\%), Rhodes grass (60.7\%), sorghum (71.4\%), and Kikuyu grass $(60.0 \%)$ in less than 0.5 acres of land. In Mosop Sub County, all households planted sorghum with majority of the respondents planting Napier (69.7\%), Rhodes grass $(50.0 \%)$, and Kikuyu grass $(60.0 \%)$ in less than 0.5 acres of land while maize (79.3\%) was planted in between 0.5 to 2 acres of land. In Nandi hills Sub County, all households planted ( 1 to 50 ) fodder trees with majority of the respondents planting Napier (79.2\%), sorghum (50.0\%) and Rhodes grass (56.5\%) in less than 0.5 acres of land while maize $(56.5 \%)$ was planted in between 0.5 to 2 acres of land. In general, Fig. 3 (a) shows that majority of farmers planted fodder in less than 0.5 acres of land for Napier (80.1\%), Rhodes grass (57.5\%), Sorghum (54\%), maize 33.4\% Kikuyu Grass (40.3\%), and Lucerne(59.4\%) and (82.1\%) planting 1 to 50 fodder Trees. A test of significance was calculated (Table 4 and Table 5) compared acreage of fodder planted with types of fodder and found statistically significant association between acreage of fodder planted and maize, sorghum and lucerne i.e. computed chi square greater than critical chi square. Similar results were found for fodder trees and the number planted. According to the Laws of Kenya (2010), freehold ownership of land has no term limit while leasehold land ownership has a term limit. In customary land ownership tenure system, the land is inherited by the next of kin (Laws of Kenya, 2010). Customary land tenure bestows rights to communal land ownership. The land is owned by the local communities and administered in accordance with their customs laws (Laws of Kenya, 2010).

Table 6 shows the importance of these fodder where $57.4 \%$, $58.0 \%, 54.5 \%, 82.8 \%, 73.3 \%$ and $77.1 \%$ respondents from $\mathrm{Al}-$ dai Sub county indicated that Napier, Rhodes grass, maize, sorghum, Lucerne and fodder trees respectively were important to dairy farming while $88.0 \%$ of respondents regarded kikuyu grass as very important to their dairy farming. In Chesumei Sub County, (80.0\%) and Lucerne were considered important whereas Rhodes grass $(71.4 \%)$, maize $(81.3 \%)$, sorghum (55.6\%), kikuyu grass $(60.9 \%)$, Lucerne $(50.0 \%)$ and fodder trees $(66.7 \%)$ were considered as very important for dairy farming. In Emgwen Sub County, Napier (59.1\%) was considered important whereas Rhodes grass $(58.6 \%)$, maize $(60.9 \%)$, 
Table 3: Main source of livestock feed per sub county

\begin{tabular}{|c|c|c|c|c|c|c|c|c|}
\hline Sub-county/Variable & & Aldai & Chesumei & Emgwen & Mosop & Nandi Hills & Total & Chi Square test \\
\hline \multirow{2}{*}{$\begin{array}{l}\text { Natural pasture from } \\
\text { communal land }\end{array}$} & Freq $(n)$ & 19.0 & 5.0 & 0.0 & 2.0 & 6.0 & 32.0 & \multirow{2}{*}{19.05} \\
\hline & Perc (\%) & 19.2 & 7.5 & 0.0 & 6.9 & 6.5 & 9.3 & \\
\hline \multirow{2}{*}{$\begin{array}{l}\text { Natural pasture from } \\
\text { own farm }\end{array}$} & Freq (n) & 86.0 & 48.0 & 46.0 & 15.0 & 69.0 & 264 & \multirow[b]{2}{*}{15.66} \\
\hline & Perc (\%) & 86.9 & 71.6 & 80.7 & 51.7 & 74.2 & 76.5 & \\
\hline \multirow{2}{*}{ Planted fodder } & Freq (n) & 39.0 & 30.0 & 25.0 & 5.0 & 27.0 & 126.0 & \multirow[b]{2}{*}{5.63} \\
\hline & Perc (\%) & 39.4 & 44.8 & 43.9 & 17.2 & 29.0 & 36.5 & \\
\hline \multirow[b]{2}{*}{ Crop residue } & Freq (n) & 62.0 & 30.0 & 21.0 & 26.0 & 33.0 & 172.0 & \multirow[b]{2}{*}{26.46} \\
\hline & Perc (\%) & 62.6 & 44.8 & 36.8 & 89.7 & 35.5 & 49.9 & \\
\hline \multirow{2}{*}{ Purchased fodder } & Freq (n) & 16.0 & 5.0 & 6.0 & 3.0 & 9.0 & 39.0 & \multirow[b]{2}{*}{3.47} \\
\hline & Perc (\%) & 16.2 & 7.5 & 10.5 & 10.3 & 9.7 & 11.3 & \\
\hline
\end{tabular}

NB: For $\chi^{2}$ test, $\mathrm{df}=4, \alpha=0.05$ and critical value $=9.48$

(Source: Research Data, 2021)

sorghum $(57.1 \%)$, kikuyu grass $(60.0 \%)$, Lucerne $(62.5 \%)$ and fodder trees $(100 \%)$ were shown to be very important to dairy farming. In Mosop, Napier and maize were shown to be very important by all respondents. In Nandi Hills, Napier (66.7\%), Rhodes grass $(73.9 \%)$, maize $(78.6 \%)$, sorghum $(86.7 \%)$, Kikuyu grass $(88.9 \%)$, and Lucerne $(80.0 \%)$ were shown to be very important to dairy farming whereas all respondents noted that fodder Trees were very important. In overall, Figure 3 (b) shows that respondents considered Rhodes grass (57.7\%), Maize (69.6) and Kikuyu grass (76.3\%) as very important while Napier (55.6\%), sorghum (55.0\%), Lucerne (52.9\%) and fodder tree $(70.0 \%)$ as important to dairy farming in the county. Previous studies including Lukuyu et al. (2011) noted that the commonly utilized feed resources that formed the highest proportion amongst the smallholder's dairy farmers in Kenya were natural pasture, Napier grass and crop residues.
The FGD noted that 20 years ago, natural pastures were mainly communal. However, communal lands are now overgrazed, and very little fodder is available with the grass growth not beyond one foot. The land sizes have also continued to decrease and hence land available for paddocking natural pastures has continued to decrease which leads to over grazing. Natural resources available and accessibly and in Nandi County include swamps rivers and forest. However, the county government has put strict measures to control what is planted on the river catchment areas and prohibited farmers from ploughing up to the riverbanks. Other strict measures include control on the use of county communal grazing areas especially swamps and forest.

\subsection{Fodder availability for future use}

Table 7, majority of respondents conserved or preserved

Table 4: Acreage of fodder planted in Nandi County

\begin{tabular}{|c|c|c|c|c|c|c|c|c|}
\hline \multirow{3}{*}{ Foddder } & \multirow{3}{*}{ Sub-county } & \multicolumn{6}{|c|}{ Acreage of fodder planted } & \multirow{3}{*}{$\begin{array}{l}\text { Chi Square } \\
\text { test }\end{array}$} \\
\hline & & \multicolumn{2}{|c|}{$<0.5$ acres } & \multicolumn{2}{|c|}{0.5 to 2 acres } & \multicolumn{2}{|c|}{$>2$ acres } & \\
\hline & & Freq $(\mathrm{n})$ & $(\%)$ & Freq $(\mathrm{n})$ & $(\%)$ & Freq $(\mathrm{n})$ & $(\%)$ & \\
\hline \multirow{5}{*}{ Napier } & Aldai & 71 & 75.5 & 20 & 21.3 & 3 & 3.2 & \multirow{5}{*}{13.59} \\
\hline & Chesumei & 42 & 93.3 & 3 & 6.7 & 0 & 0 & \\
\hline & Emgwen & 34 & 82.9 & 5 & 12.2 & 2 & 4.9 & \\
\hline & Mosop & 23 & 69.7 & 10 & 30.3 & 0 & 0 & \\
\hline & Nandi Hills & 42 & 79.2 & 8 & 15.1 & 3 & 5.7 & \\
\hline \multirow{5}{*}{ Napier } & Aldai & 28 & 56 & 20 & 40 & 2 & 4 & \multirow{5}{*}{10.55} \\
\hline & Chesumei & 18 & 64.3 & 7 & 25 & 3 & 10.7 & \\
\hline & Emgwen & 17 & 60.7 & 10 & 35.7 & 1 & 3.6 & \\
\hline & Mosop & 14 & 50 & 9 & 32.1 & 5 & 17.9 & \\
\hline & Nandi Hills & 13 & 56.5 & 5 & 21.7 & 5 & 21.7 & \\
\hline \multirow{5}{*}{ Maize } & Aldai & 4 & 36.4 & 6 & 54.5 & 1 & 9.1 & \multirow{5}{*}{19.51} \\
\hline & Chesumei & 7 & 46.7 & 3 & 20 & 5 & 33.3 & \\
\hline & Emgwen & 8 & 34.8 & 10 & 43.5 & 5 & 21.7 & \\
\hline & Mosop & 4 & 13.8 & 23 & 79.3 & 2 & 6.9 & \\
\hline & Nandi Hills & 11 & 35.5 & 11 & 35.5 & 9 & 29 & \\
\hline \multirow{5}{*}{ Sorghum } & Aldai & 9 & 31 & 19 & 65.5 & 1 & 3.4 & \multirow{5}{*}{33.57} \\
\hline & Chesumei & 8 & 88.9 & 1 & 11.1 & 0 & 0 & \\
\hline & Emgwen & 5 & 71.4 & 1 & 14.3 & 1 & 14.3 & \\
\hline & Mosop & 7 & 100 & 0 & 0 & 0 & 0 & \\
\hline & Nandi Hills & 9 & 50 & 3 & 16.7 & 6 & 33.3 & \\
\hline \multirow{5}{*}{ Kikuyu grass } & Aldai & 11 & 44 & 3 & 12 & 11 & 44 & \multirow{5}{*}{14.18} \\
\hline & Chesumei & 16 & 72.7 & 3 & 13.6 & 3 & 13.6 & \\
\hline & Emgwen & 6 & 60 & 3 & 30 & 1 & 10 & \\
\hline & Mosop & 0 & $\mathrm{Na}$ & 0 & $\mathrm{Na}$ & 0 & $\mathrm{Na}$ & \\
\hline & Nandi Hills & 5 & 25 & 6 & 30 & 9 & 45 & \\
\hline \multirow{5}{*}{ Lucerne } & Aldai & 8 & 57.1 & 6 & 42.9 & 0 & 0 & \multirow{5}{*}{19.03} \\
\hline & Chesumei & 5 & 100 & 0 & 0 & 0 & 0 & \\
\hline & Emgwen & 8 & 100 & 0 & 0 & 0 & 0 & \\
\hline & Mosop & 0 & $\mathrm{Na}$ & 0 & $\mathrm{Na}$ & 0 & $\mathrm{Na}$ & \\
\hline & Nandi Hills & 2 & 40 & 1 & 20 & 2 & 40 & \\
\hline
\end{tabular}


Table 5: Number of fodder trees planted in Nandi County

\begin{tabular}{|c|c|c|c|c|c|c|c|}
\hline \multirow{2}{*}{ Sub-county } & \multicolumn{2}{|c|}{$<50$ trees } & \multicolumn{2}{|c|}{50 to 100 trees } & \multicolumn{2}{|c|}{$>100$} & \multirow{2}{*}{$\begin{array}{l}\text { Chi- } \\
\text { square }\end{array}$} \\
\hline & Freq $(n)$ & $\%$ & Freq (n) & $\%$ & Freq (n) & $\%$ & \\
\hline Aldai & 30 & 85.7 & 5 & 14.3 & 0 & 0 & \\
\hline Chesumei & 4 & 80 & 0 & 0 & 1 & 20 & \\
\hline Emgwen & 0 & 0 & 0 & 0 & 1 & 100 & 41.31 \\
\hline Mosop & 18 & 78.3 & 5 & 21.7 & 0 & 0 & \\
\hline Nandi Hills & 3 & 100 & 0 & 0 & 0 & 0 & \\
\hline
\end{tabular}

Table 6: Importance of fodder to dairy farming

\begin{tabular}{|c|c|c|c|c|c|c|c|c|}
\hline Sub-county & Category & Napier & $\begin{array}{l}\text { Rhodes } \\
\text { grass }\end{array}$ & Maize & Sorghum & $\begin{array}{l}\text { Kikuyu } \\
\text { grass }\end{array}$ & Lucerne & $\begin{array}{l}\text { Fodder } \\
\text { Trees }\end{array}$ \\
\hline \multirow{3}{*}{ Aldai } & Not Important & 2.1 & 0 & 0 & 0 & 0 & 0 & 5.7 \\
\hline & Important & 57.4 & 58 & 54.5 & 82.8 & 12 & 73.3 & 77.1 \\
\hline & Very important & 40.4 & 42 & 45.5 & 17.2 & 88 & 26.7 & 17.1 \\
\hline \multirow{3}{*}{ Chesumei } & Not Important & 4.4 & 3.6 & 0 & 0 & 0 & 0 & 33.3 \\
\hline & Important & 80 & 25 & 18.8 & 44.4 & 39.1 & 50 & 0 \\
\hline & Very important & 15.6 & 71.4 & 81.3 & 55.6 & 60.9 & 50 & 66.7 \\
\hline \multirow{3}{*}{ Emgwen } & Not Important & 0 & 3.4 & 4.3 & 0 & 0 & 0 & 0 \\
\hline & Important & 59.1 & 37.9 & 34.8 & 42.9 & 40 & 37.5 & 0 \\
\hline & Very important & 40.9 & 58.6 & 60.9 & 57.1 & 60 & 62.5 & 100 \\
\hline \multirow{3}{*}{ Mosop } & Not Important & 0 & $\mathrm{Na}$ & 0 & $\mathrm{Na}$ & $\mathrm{Na}$ & $\mathrm{Na}$ & $\mathrm{Na}$ \\
\hline & Important & 0 & $\mathrm{Na}$ & 0 & $\mathrm{Na}$ & $\mathrm{Na}$ & $\mathrm{Na}$ & $\mathrm{Na}$ \\
\hline & Very important & 100 & $\mathrm{Na}$ & 100 & $\mathrm{Na}$ & $\mathrm{Na}$ & $\mathrm{Na}$ & $\mathrm{Na}$ \\
\hline \multirow{3}{*}{ Nandi Hills } & Not Important & 1.8 & 4.3 & 7.1 & 0 & 0 & 0 & 0 \\
\hline & Important & 31.6 & 21.7 & 14.3 & 13.3 & 11.1 & 20 & 100 \\
\hline & Very important & 66.7 & 73.9 & 78.6 & 86.7 & 88.9 & 80 & 0 \\
\hline
\end{tabular}

(Source: Research Data, 2021)

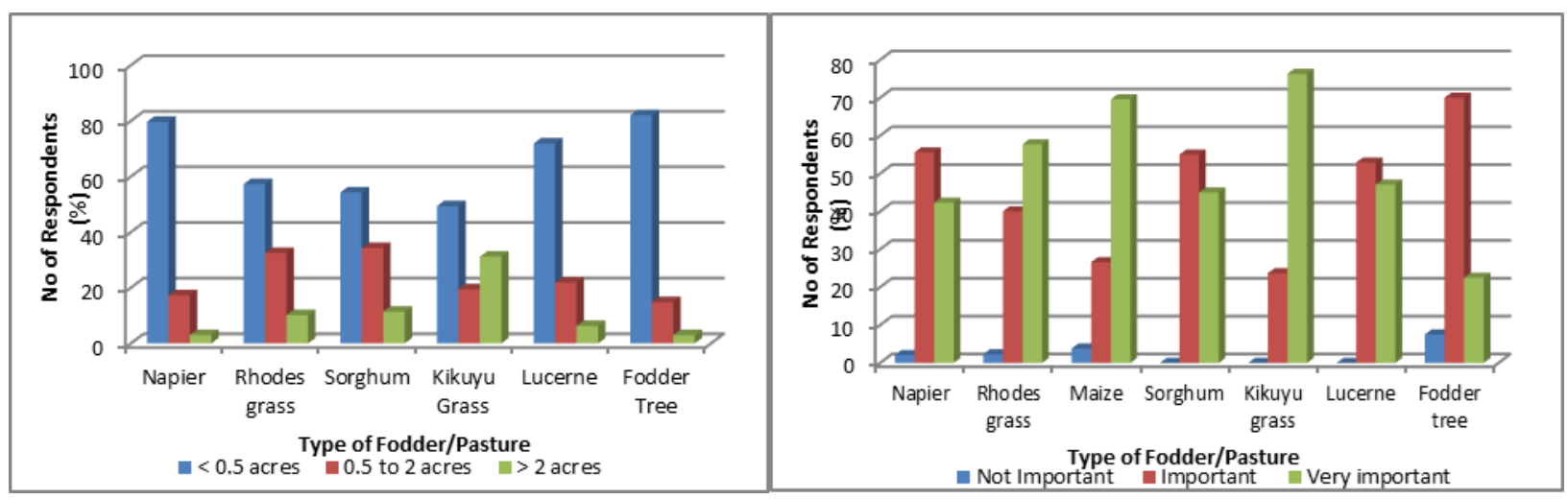

Fig. 3: Analysis of a) acreage of fodder/pasture planted and b) importance of fodder/pasture to dairy farming

(Source: Research Data, 2021)

fodder for future use in Aldai (90.9\%), Chesumei (87.1\%), Emgwen (87.3\%), Mosop (100\%) and Nandi Hills (62.5\%). Table 8 show that most of the households in Aldai (96.9\%), Chesumei (85.2\%), Emgwen (85.7\%), Mosop (96.6\%) and Nandi Hills (75.0\%) conserved/preserved crop residue. A test of significance was calculated (Table 7) to assess whether farmers conserved or preserved fodder for future use and found statistically significant association as computed chi square values were greater than critical chi square values. In overall, $88.2 \%$ of all respondents in Nandi conserved or preserved crop residue while $39.9 \%$ conserved hay and $35.4 \%$ conserved silage and thus meant that crop residue mainly maize stovers is a major feed resource followed by conserved hay and silage during drought.
Table 7: Conservation/Preservation of fodder for future use per ward

\begin{tabular}{llllll}
\hline \multirow{2}{*}{ Sub-county } & \multicolumn{2}{c}{ Yes } & \multicolumn{2}{c}{ No } & $\begin{array}{l}\text { Chi } \\
\text { Square }\end{array}$ \\
\cline { 2 - 5 } & Freq (n) & $(\%)$ & Freq (n) & $(\%)$ & \\
\hline Aldai & 100 & 90.9 & 10 & 9.1 & \\
Chesumei & 54 & 87.1 & 8 & 12.9 & \\
Emgwen & 48 & 87.3 & 7 & 12.7 & \\
Mosop & 29 & 100 & 0 & 0.0 & 40.21 \\
Nandi Hills & 60 & 62.5 & 36 & 37.5 & \\
$\begin{array}{l}\text { Overall (Nandi } \\
\text { County) }\end{array}$ & 291 & 82.7 & 61 & 17.3 & \\
\hline
\end{tabular}

NB: For $\chi^{2}$ test, $d f=4, \alpha=0.05$ and critical value $=9.49$ (Source: Research Data, 2021) 
Studies show that when treated crop residue could be a cheap source of feed resource (Owen and Jayasuriya, 1989) that can be used during feed scarcity during dry season that is expected to exacerbate as result of climate change. The FGD noted that natural pastures were most available to the farmers in terms of access. Farmers noted that they could access natural pastures from their own farms or lease them from neighbours. Other ways in which farmers accessed natural pasture was through barter trade where a dairy farmer can graze the animals and in return pay by giving the owner of land the milk. The FGD also noted that Napier grass were also easily available as farmers could easily get planting materials from neighbours. Availability of Rhodes grass was limited as they were mostly sold and sometimes farmers had to go great distances to access them whereas access to silage from Maize and Sorghum were limited since only few farmers make their silage. For maize stovers, they were readily available after maize harvest but limited by farmer's knowledge on processing and preservation.

Table 8: Type of fodder conserved/preserved

\begin{tabular}{|c|c|c|c|c|c|c|c|c|}
\hline \multirow{2}{*}{ Sub-county } & \multicolumn{2}{|c|}{ Crop residues } & \multicolumn{2}{|c|}{ Hay } & \multicolumn{2}{|l|}{ Silage } & \multicolumn{2}{|c|}{ Wheat straw } \\
\hline & Freq (n) & (\%) & Freq (n) & (\%) & Freq (n) & $(\%)$ & Freq (n) & $(\%)$ \\
\hline Aldai & 93 & 96.9 & 22 & 22.9 & 30 & 31.3 & 4 & 4.2 \\
\hline Chesumei & 46 & 85.2 & 26 & 48.1 & 13 & 24.1 & 2 & 3.7 \\
\hline Emgwen & 42 & 85.7 & 17 & 34.7 & 21 & 42.9 & 0 & 0.0 \\
\hline Mosop & 28 & 96.6 & 27 & 93.1 & 21 & 72.4 & 1 & 3.4 \\
\hline Nandi Hills & 45 & 75.0 & 23 & 38.3 & 17 & 28.3 & 0 & 0.0 \\
\hline Total & 254 & 88.2 & 115 & 39.9 & 102 & 35.4 & 7 & 2.4 \\
\hline
\end{tabular}

\subsection{Resilience and adaptation approaches used to address cli- mate change}

The dairy farmers have adapted a variety of coping strategies to mitigate against impacts of climate change. Table 9, $18 \%$ of households in Aldai Sub County used conserved hay/silage, $42.3 \%$ bought commercial feeds, $85.6 \%$ used crop residue, and $27 \%$ sold their animals while less than $10 \%$ moved their animals to friends and relatives to avert the negative effects of climate change. In Chesumei Sub County, 59.4\% of households used conserved hay/silage, 39.1\% bought commercial feeds, $53.1 \%$ used crop residue, and $14.1 \%$ sold their animals while less than $5 \%$ moved their animals to friends and relatives to avert the negative effects of climate change. In Emgwen Sub County, $47.5 \%$ of households used conserved hay/silage $40.7 \%$ bought commercial feeds, $88.1 \%$ used crop residue, and
$32.2 \%$ sold their animals while less than 5\% moved their animals to friends and relatives to avert the negative effects of climate change. In Mosop Sub County, 93.9\% of households used conserved hay/silage $84.8 \%$ bought commercial feeds, $90.9 \%$ used crop residue, and $51.5 \%$ moved their animals to friends and relatives while less than $5 \%$ sold their animals to avert the negative effects of climate change. In Nandi Hills Sub County, $45.3 \%$ of households used conserved hay/silage $25.3 \%$ bought commercial feeds, $62.1 \%$ used crop residue while less than $10 \%$ either sold their animals or moved their animals to friends and relatives to avert the negative effects of climate change. It was noted that in Nandi County, methods used to address negative experiences of climate change included use conserved hay/ silage $(44.2 \%)$, buying of commercial feeds $(40.9 \%)$, use crop residue $(74.6 \%)$, moving of animals to other farms $(8.8 \%)$ and selling of animals (17.4\%).

Table 9: Methods used to address negative experiences of climate change

\begin{tabular}{llllll}
\hline Sub County & $\begin{array}{l}\text { Use conserved } \\
\text { hay/ silage }\end{array}$ & $\begin{array}{l}\text { Buy commer- } \\
\text { cial feeds }\end{array}$ & $\begin{array}{l}\text { Use crop } \\
\text { residue }\end{array}$ & $\begin{array}{l}\text { Move animals } \\
\text { to other farms }\end{array}$ & Sell animals \\
\hline Aldai & 18.0 & 42.3 & 85.6 & 7.2 & 27.0 \\
Chesumei & 59.4 & 39.1 & 53.1 & 4.7 & 14.1 \\
Emgwen & 47.5 & 40.7 & 88.1 & 3.4 & 32.2 \\
Mosop & 93.9 & 84.8 & 90.9 & 51.5 & 3.0 \\
$\begin{array}{l}\text { Nandi Hills } \\
\begin{array}{l}\text { Overall (Nandi } \\
\text { County) }\end{array}\end{array}$ & 45.3 & 25.3 & 62.1 & 2.1 & 4.2 \\
\hline
\end{tabular}

(Source: Research Data, 2021)

\subsection{Resilience and Adaptation measures to prevent negative experience related to climate change}

Table 10 shows that more than $60 \%$ of households in each ward in Nandi County had initiated farming practices to reduce the effects in an event of a negative impact related to climate change. Respondents in Aldai, Chesumei, Emgwen, Mosop and
Nandi Hills sub counties showed 78.7\%, 86.2\%, 77.6\%, 100\% and $73.9 \%$ respectively that they had measures to help them avert negative climate change. In overall, $80.7 \%$ of respondents in Nandi County had put measures in place to avert similar negative experiences of climate change against 19.3\% who had not measured in place. It is noted that these measures included 
adoption of new fodder types/ varieties, adoption of new planting methods, intercropping different fodder, conservation, and preservation practices. A test of significance was calculated ( Table 10) analysed on the existence of preventive measures to negative climate change found statistically significant association as computed chi square values were greater than critical chi square values.

In Table 11, adoption of new planting methods and intercropping different fodder was not recognised by majority of respondents in Nandi County as less than $50 \%$ of the respondents identified the approaches as a measure to prevent negative impact impacts of climate change. In overall, respondents identified adoption of fodder types/varieties (54.7\%), adoption of new planning methods (12.9\%), intercropping different fodder $(13.2 \%)$ and conservation and preservation practices (70\%) as measures put in place to prevent similar negative experience related to climate change in Nandi County. Table 12 shows that significant percentage of more than $80 \%$ of all respondents in all sub counties indicated that they used disease control. in addition, breeding using AI was very popular in Kobujoi (62.5\%), Kosirai (100\%), Ngechek (76.7\%), Kilibwoni (71.2\%), Kabisaga (100\%), Kabiyet (92.9\%), Chepkunyuk (75.0\%) and Lessos (76.9\%). The study also found that the use of biogas was also practised by a low percentage of respondents with none of the wards or sub counties exceeding 6\%. A review by Rojas-Downing et al. (2017) showed that climate change adaptation, miti- gation practices, and policy frameworks are critical to protect livestock production. The review found that diversification of livestock animals (within species), using different crop varieties, and shifting to mixed crop-livestock systems seemed to be the most promising adaptation measures. In addition, shifting to mixed crop-livestock systems can improve efficiency by increasing production with the use of fewer resources. On mitigation side, Rojas-Downing et al. (2017) noted that improvement of animal nutrition and genetics are important because enteric fermentation is a major GHG emitter in livestock production.

However, the efficacy of these practices in reducing emissions is uncertain and more research is needed concerning effective mitigation practices. related to enteric fermentation.

Table 10: Existence of preventive measures to negative climate change

\begin{tabular}{|c|c|c|c|c|c|}
\hline \multirow{2}{*}{ Sub County } & \multicolumn{2}{|c|}{ Yes } & \multicolumn{2}{|c|}{ No } & \multirow{2}{*}{$\begin{array}{l}\text { Chi- } \\
\text { square }\end{array}$} \\
\hline & Freq(n) & $\%$ & Freq(n) & $\%$ & \\
\hline Aldai & 85 & 78.7 & 23 & 21.3 & \multirow{6}{*}{12.40} \\
\hline Chesumei & 56 & 86.2 & 9 & 13.8 & \\
\hline Emgwen & 45 & 77.6 & 13 & 22.4 & \\
\hline Mosop & 33 & 100.0 & 0 & 0.0 & \\
\hline Nandi Hills & 65 & 73.9 & 23 & 26.1 & \\
\hline Total & 284 & 80.7 & 68 & 19.3 & \\
\hline
\end{tabular}

NB: For $\chi^{2}$ test, $d f=4, \alpha=0.05$ and critical value $=9.49$

(Source: Research Data, 2021)

Table 11: Mitigation measures to negative effect of climate change

\begin{tabular}{|c|c|c|c|c|c|c|c|c|}
\hline \multirow{2}{*}{ Sub County } & \multicolumn{2}{|c|}{$\begin{array}{l}\text { Adoption of new fodder types/ } \\
\text { varieties }\end{array}$} & \multicolumn{2}{|c|}{$\begin{array}{l}\text { Adoption of new planning } \\
\text { methods }\end{array}$} & \multicolumn{2}{|c|}{$\begin{array}{l}\text { Intercropping different } \\
\text { fodder }\end{array}$} & \multicolumn{2}{|c|}{$\begin{array}{c}\text { conservation and preserva- } \\
\text { tion practices }\end{array}$} \\
\hline & Freq (n) & $(\%)$ & Freq (n) & $(\%)$ & Freq (n) & $(\%)$ & Freq (n) & $(\%)$ \\
\hline Aldai & 37 & 42.0 & 20 & 22.7 & 17 & 19.3 & 59 & 67.0 \\
\hline Chesumei & 27 & 46.6 & 8 & 13.8 & 4 & 6.9 & 48 & 82.8 \\
\hline Emgwen & 18 & 40.0 & 2 & 4.4 & 3 & 6.7 & 43 & 95.6 \\
\hline Mosop & 32 & 97.0 & 1 & 3.0 & 3 & 9.1 & 1 & 3.0 \\
\hline Nandi Hills & 43 & 68.3 & 6 & 9.5 & 11 & 17.5 & 50 & 79.4 \\
\hline Total & 157 & 54.7 & 37 & 12.9 & 38 & 13.2 & 201 & 70.0 \\
\hline
\end{tabular}

(Source: Research Data, 2021)

Table 12: Adoption of Climate Smart Agricultural technologies

\begin{tabular}{|c|c|c|c|c|c|c|c|c|c|c|c|c|c|c|}
\hline \multirow{2}{*}{ Sub County } & \multicolumn{2}{|c|}{ Compost making } & \multicolumn{2}{|c|}{ Use of biogas } & \multicolumn{2}{|c|}{ Water conservation } & \multicolumn{2}{|c|}{ Disease control } & \multicolumn{2}{|c|}{$\begin{array}{c}\text { Planting fodder } \\
\text { trees }\end{array}$} & \multicolumn{2}{|c|}{$\begin{array}{c}\text { Reducing number } \\
\text { of animals }\end{array}$} & \multicolumn{2}{|c|}{$\begin{array}{c}\text { Breeding (using } \\
\text { AI) }\end{array}$} \\
\hline & Freq (n) & $(\%)$ & Freq (n) & $(\%)$ & Freq (n) & $(\%)$ & Freq (n) & $(\%)$ & Freq (n) & $(\%)$ & Freq (n) & $(\%)$ & Freq (n) & $(\%)$ \\
\hline Aldai & 40 & 33.1 & 1 & 0.8 & 100 & 82.6 & 120 & 99.2 & 36 & 29.8 & 44 & 36.4 & 38 & 31.4 \\
\hline Chesumei & 3 & 5.4 & 2 & 3.6 & 12 & 21.4 & 54 & 96.4 & 15 & 26.8 & 13 & 23.2 & 46 & 82.1 \\
\hline Emgwen & 5 & 8.5 & 4 & 6.8 & 14 & 23.7 & 57 & 96.6 & 11 & 18.6 & 21 & 35.6 & 42 & 71.2 \\
\hline Mosop & 0 & 0.0 & 0 & 0.0 & 9 & 27.3 & 33 & 100 & 25 & 75.8 & 31 & 93.9 & 32 & 97.0 \\
\hline Nandi Hills & 20 & 20.6 & 2 & 2.1 & 72 & 74.2 & 85 & 87.6 & 23 & 23.7 & 25 & 25.8 & 74 & 76.3 \\
\hline Total & 68 & 18.6 & 9 & 2.5 & 207 & 56.6 & 349 & 95.4 & 110 & 30.1 & 134 & 36.6 & 232 & 63.4 \\
\hline
\end{tabular}

(Source: Research Data, 2021)

\section{Conclusion and recommendation}

The study sought to assesses adaptation and mitigation strategies to climate change by smallholder dairy farmers in the Nandi county of Kenya. The study showed that males are more involved in smallholder dairy farming than their female. Majority of households had between 4 and 6 people with $54.6 \%$ of $\mathrm{HH}$ heads above the age of 46 and thus older population considered less productive but more settled and experienced compared to younger population who were considered innovative. In addition, most of the $\mathrm{HH}$ head had attained primary education and above in all sub counties of Nandi County with the study taking note that farmers with formal education were more likely to 
adopt new technologies and are also more innovative.

Over $80 \%$ of respondents are mainly dependent on farming as a source of income in Nandi County. In terms of wealth status, 94.9\% owned Radio and Television while 96.5\% owned cell phones. A significant relationship exists between household type and age group, level of education, Occupation, source of Income and household ownership (Cell phone, Solar Panel, Vehicle, Tractor). In addition, most household mainly depended on natural pastures on their own farms as a source of feed. Natural pastures and fodder crops grown that were considered most important in terms of providing feed for the cows mainly comprised of Kikuyu grass, and Nandi Sateria. Most farmers also utilized maize crops for their animals with a few of them planting maize for making silage while others use green maize stock after selling maize cob. Majority of farmers planted fodder in less than 0.5 acres of land for Napier, Rhodes grass, Sorghum, and Lucerne. Further, most smallholder dairy farmers planted between 1 and 50 fodder Trees.

Overall, smallholder dairy farmers conserved/preserved crop residue mainly from maize stovers which acted as a major feed resource during drought. The dairy farmers have adapted a variety of coping strategies to mitigate against impacts of climate change. Methods used to address negative experiences of climate change included use conserved hay/silage, buying of commercial feeds, use crop residue, moving of animals to other farms and selling of animals. Measures put in place to avert similar negative experiences of climate change which included adoption of new fodder types/varieties, adoption of new planting methods, intercropping different fodder, conservation, and preservation practices. In addition, majority of smallholder dairy farmers identified adoption of fodder types/varieties, adoption of new planting methods, intercropping different fodder and conservation and preservation practices respectively as measures put in place to prevent similar negative experience related to climate change.

The study recommends that dairy farmers should be empowered to adapt and mitigate against the effects of drought and emergence of new vectors and livestock diseases occasioned by extreme weather variability. There is need to develop climate smart fodder varieties/production methods. As a response to the effects of climate change and change, dairy farmers should invest in fodder productivity and conservation to sustain their dairy herd productivity. Adequate mechanisms should be put in place to minimize losses of fodder and dairy herd productivity occasioned by increased frequency of extreme rainfall over the study area. Effective adaptation and mitigation measures to address climate change and milk production should also be scaled up through policy. Moreover, policy makers need to not only promote use of climate smart fodder varieties/production methods but also mainstreaming climate change information into development planning, budgeting and implementation at national and county levels.

\section{References}

Chapman SC, Chakraborty S, Fernanda Dreccer M and Mark Howden S (2012). Plant adaptation to climate change - opportunities and priorities in breeding. Crop and Pasture Science 63, 251-268. https://doi.org//10.1071/ CP11303
Chaudhury, M., Kristjanson, P., Kyagazze, F., Naab, J., \& Neelormi, S. (2012). Participatory Gender-sensitive Approaches for Addressing Key Climate Change-related Research Issues: Evidence from Bangladesh, Ghana, and Uganda. CCAFS Working Paper 19. Google scholar

CGIAR. (2015). Climate Smart Agriculture 101. Resource Library. Montpellier, France: Consultative Group for International Agricultural Research.

FAO. (2010). Dairy development in Kenya. FAO, Rome, Italy.

FAO, (2015). The State of Food Insecurity in the World Meeting. The 2015 International Hunger Targets: Taking Stock of Uneven Progress. FAO, Rome, Italy. https://doi.org/10.3945/an.115.009936

Gallina, A. (2016). Gender dynamics in dairy production in Kenya: A literature review. Copenhagen, Denmark: CGIAR Research Program on Climate Change, Agriculture and Food Security.

Gerald Katothya. (2017). Gender assessment of dairy value chains: evidence from Kenya, Rome, FAO. Google scholar

Henry, B., Charmley, E., Eckard, R., Gaughan, J.B., Hegarty, R., (2012). Livestock production in a changing climate: adaptation and mitigation research in Australia. Crop Pasture Sci. 63, 191-202. https://doi.org/10.1071/CP11169

Herrero, M., K, T. P., A, N., Msangi, S., S, W., Kruska, R.,... P, P. R. (2009). Drivers of change in crop-livestock systems ecosystems services and human well-being to 2030. Google scholar

Hobbs , P., Gollin , K., \& Gupta , R. (2008). The Role of Conservation Agriculture in Sustainable Agriculture,.Philosophical Transactions of the Royal Society , 363, pp. 543-555. https://doi.org/10.1098/rstb.2007.2169

IPCC. (2007). Climate Change 2007: synthesis report. Contribution of Working Groups I, II and III to the Fourth Assessment Report of the Intergovernmental Panel on Climate Change (Eds. Core Writing Team, Pachauri R. K. , . Geneva, Switzwerland: United Nations. Google scholar

IPCC (Intergovermental Panel on Climate Change), (2013). Climate change 2013: The physical science basis. In: Stocker, T.F., Qin, D., Plattner, G.-K., Tignor, M., Allen, S.K., Boschung, J., Nauels, A., Xia, Y., Bex, V., Midgley, P.M. (Eds.), Contribution of Working Group I to the Fifth Assessment Report of the Intergovernmental Panel on Climate Change. Cambridge University Press, Cambridge, United Kingdom and New York, NY, USA, p. 1535. http:// dx.doi.org/10.1017/CBO9781107415324

Krejcie, R., and Morgan , D. (1970). Determining Sample Size for Research Activities. Educational and Psychological Measurement, 607-610. https:// doi.org/10.1177\%2F001316447003000308

Mibey, M. C. (2015). Factors influencing youth involvement in agribusiness projects in Bomet Central Sub-county, Kenya, Unpublished project, University of Nairobi. Google scholar

Lukuyu B. A, K. A. (2011). Constraints and options to enhancing production of high quality feeds in dairy production in Keny,Uganda and Rwanda ICRAF. Working Paper no. 95. Nairobi, Kenya: World Agroforestry Centre. Google scholar

Nardone, A., Ronchi, B., Lacetera, N., Ranieri, M.S., Bernabucci, U., 2010. Effects of climate change on animal production and sustainability of livestock systems. Livest. Sci. 130, 57-69. https://doi.org/10.1016/j.livsci.2010.02.011

Njaruai, D., Gatheru, M., Wambua, M., Nguluu, S., Mwangi, M. \& Keya, A. (2012). Feeding management for dairy cattle in smallholder farming systems of semi-arid tropical Kenya.Nairobi, Livestock Research for Rural Development. Google scholar

Njeru, K., Gichimu, B. M., Lopokoiyit, M.C. \& Mwangi, J.G. (2015) Influence of Kenyan youth's perception towards agriculture and necessary interventions; A Review- Asian Journal of Agricultural Extension, Economics \& Sociology 5(1). https://doi.org/10.9734/AJAEES/2015/15178

Owen, E., Jayasuriya, M.C.N., (1989b). Use of crop residues as animal feeds in developing countries. Res. Dev. Agric. 6, 129-138. Google scholar

Polley, H.W., Briske, D.D., Morgan, J.A., Wolter, K., Bailey, D.W., Brown, J.R., 2013. Climate change and North American rangelands: trends, projections, and implications. Rangeland Ecol. Manage. 66, 493-511. https://doi. org/10.2111/REM-D-12-00068.1

Republic of Kenya. (2008). National Livestock Policy.

Rojas-Downing, M. M., A. P. Nejadhashemi, T. Harrigan, and S. A. Woznicki, (2017). Climate change and livestock: Impacts, adapta-tions, and mitigation. Clim. Risk Manage. 16:145-163. https://doi.org/10.1016/j.crm.2017.02.001 TEGEMEO, (2011). Productivity Trends and Performance. Nairobi: Tegemeo Institute of Agricultural Policy and Development. 